\title{
Kekerasan atas Nama Agama vis a vis Amar Makruf Nahi Mungkar
}

Hasan Su'aidi

Sekolah Tinggi Agama Islam Negeri Pekalongan

hasansuaidi@yahoo.com

Abstract: Intact understanding towards the teaching of amr ma'rüf and nahy mungkar is strongly required, in support of avoiding harshness which uses religion. Hadith, as a basic of religion, is so often understood without integral comprehension. Consequently, 'harshness' within Amar makruf nahi mungkar is perceived as indication of a person's strong faith, and the only way to perform Amar makruf nahi mungkar. This writing tries to give proportional understanding of Amar makruf nahi mungkar which is taught by the religion and is different from the religious harshness.

Keywords: Harshness, Amar makruf nahi mungkar.

Abstrak: Pemahaman utuh terhadap ajaran untuk Amar makruf nahi mungkar sangat diperlukan, demi menghindari praktik-praktik kekerasan yang mengatasnamakan agama. Hadìts sebagai salah satu dari dasar agama yang dengan jelas menunjukkan cara-cara Amar makruf nahi mungkar seringkali dipahami tidak menyeluruh, sehingga "kekerasan" dalam Amar makruf nahi mungkar dipahami sebagai indikasi kekuatan iman seseorang dan cara utama dalam amr ma'rūf. Tulisan ini berusaha mendudukkan pemahaman yang proporsional tentang Amar makruf nahi mungkar yang dianjurkan agama yang sama sekali berbeda dari kekerasan agama.

Kata Kunci: Kekerasan, Amar makruf nahi mungkar. 


\section{Pendahuluan}

Di Indonesia, praktik kekerasan dengan mengatasnakmakan agama sangat marak, sebagai contoh, peristiwa kekerasan sebagai aksi dari deklarasi gerakan AKKBB (Aliansi Kebangkitan untuk Kebebasan Beragama dan Berkeyakinan), teror bom di dua hotel berbintang yang disinyalir sebagai asset Amerika yaitu Hotel JW Marriot dan Ritz Carltlon yang memakan korban sembilan tewas dan puluhan luka-luka, dan yang terakhir adalah terjadinya penyerangan terhadap kelompok Ahmadiyah di Serang dan kota-kota lain di Indonesia. Peristiwa-peristiwa itu selalu melibatkan sebagian kelompok agama tertentu yang kontra terhadap kejadian dan realitas sosial yang dinilai sebagai perbuatan yang mungkar dan harus diperangi. Aksi-aksi tersebut pada satu sisi dianggap sebagai perwujudan dari ajaran agama khususnya terkait dengan perintah Amar makruf nahi mungkar, namun pada satu sisi lainnya, dianggap sebagai aksi kekerasan atas nama agama.

Melihat fenomena di atas, maka kajian ulang terhadap kekerasan atas nama agama yang dikaitkan dengan perintah amar makruf nahi mungkar seperti apa yang dikehendaki oleh syāri“ (legislator yang dalam hal ini adalah Nabi Muhammad) melalui Hadīts atau meminjam istilah yang digunakan oleh Fazlur Rahman adalah verbal tradition $^{1}$ menjadi sangat penting. Hal ini demi mendudukkan ajaran amar makruf nahi mungkar pada porsinya yang tepat.

Tema pembahasan tentang amar makruf nahi mungkar sudah sangat sering dibicarakan, karena tema tersebut merupakan ajaran pokok dari agama Islam. Banyak literatur membahas tema ini, di antaranya Salmān ibn Fahd dan Faḍlī Ilāhī al-'Awdah dengan bukunya amar makruf nahi mungkar; Ibn Taymīyah menulis Qawāid Muhimmah fì al-Amr bil-Ma'rüf wa-al-Nahy 'an al-Munkar 'alá Daw' al-Kitāb wa-al-Sunnah; dan Khālid ibn 'Utsmān al-Sabt dengan al-Amr bil-Ma'rüf wa-al-Nahy 'an al-Munkar Usüluhu waDawābițhu wa-Ādābuh. Buku-buku tersebut saling melengkapi satu sama lainnya. Namun demikian, buku-buku tersebut lebih kepada pembahasan umum tentang amr ma'rūf, praktik amr ma'rūf dan lain-lain, tetapi tidak membahas secara khusus tema tentang kekerasan yang dihubungkan dengan ajaran agama. Oleh karena itu, 
reaktualisasi ajaran tentang amr ma'rūf nahy mungkar perlu digagas, demi menghindari pemahaman salah terhadap legalisasi kekerasan yang seringkali dikaitkan dengan agama tertentu.

Dengan maraknya praktik kekerasan yang mengatasnamakan agama seperti dikemukakan di atas, maka artikel/tulisan ini ingin menjawab sebuah pertanyaan besar yaitu: Apakah agama melegalkan tindak kekerasan dalam melakukan amr ma'rūf nahy mungkar? Untuk menjawab pertanyaan ini, metode yang digunakan di dalam artikel ini adalah library research dengan cara mengolah seluruh data yang ada di dalam berbagai literatur yang membahas tentang amar makruf nahi mungkar, untuk kemudian dilakukan telaah secara menyeluruh tentang adakah agama (dalam hal ini Islam) melegalkan tindak kekerasan di dalam keperluan melakukan amar makruf nahi mungkar.

Tulisan ini dibagi menjadi beberapa bagian, dimulai dengan pendahuluan yang membahas tentang defīnisi amar makruf nahi mungkar, unsur-unsur praktik amar makruf nahi mungkar, pembahasan meliputi amar makruf nahi mungkar dan kekerasan agama dalam prespektif Hadīts serta pendapat para ulama dan penutup yang meliputi kesimpulan dan saran.

\section{Definisi Amar Makruf Nahi Mungkar}

Amar ma'rūf nahy mungkar merupakan ajaran pokok dan jiwa (ruh) dari risalah para Nabi, sebab tanpa amar makruf nahi mungkar, tidak ada keteraturan dalam kehidupan dan semakin banyak ditemukan fitnah dan kerusakan. ${ }^{2}$ Banyak ditemukan dalil atau nas, baik al-Qur'ān maupun Hadīts yang menjelaskan tentang kewajiban untuk ber-amar makruf nahi mungkar. Di antara ayat al-Qur'ān yang menjelaskan tentang keutamaan dan kewajiban beramar makruf nahi mungkar adalah fïrman Allah dalam QS. Ālu 'Imrān/3:104, yang artinya: "Dan Hendaklah ada di antara kalian umat yang mengajak kepada kebaikan dan memerintahkan kepada perbuatan ma'rüf serta mencegah terjadinya kemungkaran dan mereka adalah orang-orangyang beruntung." Juga Firman Allah dalam QS. 'Ālu 'Imrān/3:113-114 yang artinya: "Tidaklah sama di antara ahli kitab umat yang tegak berdiri dan membaca tanda-tanda kekuasaan Allah pada waktu malam 
dan bersujud, mereka beriman kepada Allah dan hari akhir, mereka memerintahkan berbuat kebajikan dan mencegah kemungkaran, mereka berlomba-lomba di dalam kebaikan, mereka itulah orang-orang saleh."

Ayat-ayat al-Qur'ān di atas menegaskan tentang pentingnya melakukan amar makruf nahi mungkar. Namun demikian, pelaksanaan terhadap ajaran amar makruf nahi mungkar seringkali dilakukan dengan cara-cara yang justru di dalam prespektif agama tidak dapat dibenarkan, bahkan dapat dikategorikan dengan kekerasan yang mengatasnamakan agama. Artinya bahwa tidak semua tindakan amar makruf nahi mungkar yang dilakukan oleh seseorang dinilai tepat oleh agama. Dengan demikian, maka perlu kajian ulang terhadap konsep amar makruf nahi mungkar. Untuk menghindari salah paham terhadap terminologi amar makruf nahi mungkar, dan untuk menghindarkan tercampur aduknya dengan kekerasan atas nama agama, maka pada tulisan ini akan dijelaskan pengertian dari amar makruf nahi mungkar.

Ma'rūf adalah kata dari bahasa Arab ma'rūf diambil dari kata ma'rifah yang menurut bahasa Arab maknanya ialah segala sesuatu yang diketahui oleh hati, dan jiwa menjadi tenteram kepadanya. Sedangkan secara syarì dicintai oleh Allah, seperti taat kepada Allah dan berbuat baik kepada sesama. ${ }^{3}$ Sedangkan mungkar menurut bahasa, maknanya adalah segala sesuatu yang diingkari oleh jiwa, tidak disukai dan tidak dikenalnya. Mungkar adalah lawan kata dari ma'rüf, dan secara syar'i maknanya adalah segala sesuatu yang dikenal keburukannya secara $\operatorname{syar}^{\prime} \bar{i}$ dan akal, seperti maksiat kepada Allah dan zalim kepada sesama makhluk.

Berdasarkan kepada dua defīnisi tersebut, maka dapat dijelaskan hal-hal sebagai berikut. Pertama, standar untuk mengetahui ma'rüf dan mungkar itu bukanlah adat dan kebiasaan manusia serta segala sesuatu yang dipraktikkan di tengah-tengah masyarakat. Karena adat manusia itu tidak tetap, sebab boleh jadi sekarang mereka menganggap baik suatu perbuatan, dan bukan mustahil pada masa tertentu mereka mengingkari dan menentangnya, begitu pula sebaliknya. Dengan demikian maka standar untuk menentukan ma'rüf dan mungkar adalah syara' bukan adat kebiasaan. ${ }^{4}$ Kedua, pada dasarnya 
masyarakat Muslim mengenal perbuatan yang ma'rūf kemudian menyetujui, rela dan memerintahkannya, dan mereka mengingkari suatu kemungkaran, menolak dan mencegahnya. ${ }^{5}$

\section{Amar Makruf Nahi Mungkar vis a vis Kekerasan Agama}

Ajaran-ajaran agama yang baik dan agung tidak selamanya dipahami secara benar oleh penganutnya, sehingga tidak jarang jika ajaran tersebut menjadi sesuatu yang jauh dari apa yang dikehendaki oleh agama itu sendiri. Hal yang sama juga terjadi dalam praktik amar makruf nahi mungkar. Seperti yang kita ketahui di masyarakat, banyak sekali praktik-praktik kekerasan yang dilakukan oleh perorangan maupun kelompok terhadap orang atau kelompok tertentu dengan mengatasnamakan agama. Tindakan tersebut dipahami oleh penganutnya sebagai bentuk dari amar makruf nahi mungkar, bahkan cara-cara tersebut diyakini sebagai cara yang paling tinggi dalam pelaksanaan ajaran amr ma'rūf tersebut.

Menurut informasi di media disebutkan bahwa data The Wahid Institute menunjukkan sejak Januari hingga November 2008, di Indonesia terjadi 232 kasus yang melibatkan agama. Kasus-kasus tersebut dibagi ke dalam delapan kategori, yaitu penyesatan, kekerasan berbasis agama, regulasi bernuansa agama, konflik tempat ibadah, kebebasan berpikir dan berekspresi, hubungan antarumat beragama, fatwa keagamaan, dan isu-isu moralitas serta pornografī. Kekerasan berbasis agama menjadi kasus terbanyak, yaitu 55 kasus. $^{6}$

Jauh sebelum itu, masih menurut The Wahid Institute, setelah pemilihan presiden tahun 2004, dari tanggal 22 Maret 2004 hingga 22 Februari 2006 telah terjadi beberapa peristiwa kekerasan yang mengatasnamakan agama yaitu sebanyak 26 kasus yang tersebar di beberapa daerah dan provinsi di Indonesia. ${ }^{7}$ Kasus kekerasan ini, kalau dirata-rata dalam sebulan selama setahun telah terjadi 2 kasus dalam setiap bulannya. Itu pun dilakukan oleh beberapa kelompok masyarakat. Sementara itu terungkap bahwa salah satu ormas tertentu (FPI) melakukan tindak kekerasan sebanyak kurang lebih 35 kasus. $^{8}$

Menarik diungkapkan pada tulisan ini, sebuah analisis yang dikemukakan oleh Jajang Jahroni salah seorang penggiat Jaringan Islam Liberal (JIL) mengatakan bahwa memang tidak semua bentuk 
dan jenis kekerasan keagamaan dapat dinisbatkan pada pemahaman agama yang tekstual dan Islamisme. Masih ada variabel lain yang turut menyumbang terjadinya perilaku kekerasan agama. Namun dibanding variabel lainnnya, kedua variabel ini paling signifikan dalam mendorong timbulnya perilaku kekerasan agama. Di samping mendorong perilaku kekerasan agama, tekstualisme dan Islamisme juga berkorelasi positif dengan perilaku kekerasan umum dan kekerasan negara. ${ }^{9}$

Pernyataan tersebut dapat dibenarkan, jika melihat bahwa ada beberapa ajaran agama (Islam) yang secara tersurat mewajibkan melakukan amar makruf nahi mungkar dengan berbagai cara, salah satunya adalah dengan "tangan" (seperti yang terdapat di dalam Hadīts riwayat 6 perawi Hadīts selain al-Bukkhārī) bahkan hal itu dijadikan sebagai indikasi kesempurnaan iman seseorang. Pemahaman inilah yang seringkali berkembang serta diyakini oleh sebagian umat Islam. Padahal hal itu bukan merupakan satu-satunya pemahaman yang ada. Dengan demikian, maka telaah dan penerapan terhadap pemaknaan teks-teks agama menjadi sangat penting, termasuk kajian terhadap Hadìts yang terkait dengan amar makruf nahi mungkar. Karena tidak semua bentuk penentangan terhadap fenomena yang ada di masyarakat adalah implementasi dari ajaran amar makruf nahi mungkar.

\section{Varian Amar Makruf Nahi Mungkar}

Penjelasan tentang amar makruf nahi mungkar, banyak ditemukan di dalam ayat al-Qur'ān maupun Hadìts Nabi. Bahkan hal itu sudah menjadi konsensus (ijmā) para ulama seperti yang diriwayatkan oleh Ibn 'Ațīyah, al-Nawawī dan Abū al-Ma ālī al-Juwaynī. ${ }^{10}$ Namun demikian, hukum amr ma'rūf tidak hanya wajib, etapi beragam sesuai dengan situasi dan kondisi. Hal itu dapat dilihat sebagaimana rincian sebagai berikut:

Wajib, jika perkara yang menjadi obyek amr ma'rūf wajib dan obyek nahy mungkar haram. Sunnah, jika perkara yang menjadi obyek amr ma'rūf adalah sunnah dan obyek nahy mungkar makruh. Haram, jika tindakan amr ma'rūf nahy mungar dapat menimbulkan hilangnya maslahat yang lebih penting serta menyebabkan fitnah atau 
kerusakan yang lebih besar. ${ }^{11}$

Dari beragam hukum amr ma'rūf di atas, maka bisa jadi hukum yang ketiga merupakan hukum dari praktik kekerasan yang mengatasnamakan agama.

\section{Telaah Hadīts Amar Makruf Nahi Mungkar Prespektif Kitab Syarah Hadīts}

Di dalam tulisan ini perlu diungkap beberapa keterangan dari kitab-kitab syarh (penjelas) Hadīts. Hal ini dilakukan guna mengetahui bagaimana para muhaddits yang memunyai "otoritas khusus" dalam bidang Hadīts menjelaskan tentang kandungan Hadìts yang terkait dengan amar makruf nahi mungkar. Dalam hal ini, syarh kitab Hadīts yang digunakan penulis di antaranya adalah: Syarh alNawawi 'alá Muslim, Tuhfat al-Ahwazì Syarh Sahīh al-Tirmìzī, Syarh Sunan al-Nasā̄ì, Hāsyiyat al-Sindì 'alá Ibn Mājah. Penjelasan terhadap Hadìts tentang amar makruf nahi mungkar di atas, yang diambil dari keempat kitab syarh Hadīts tersebut akan dijelaskan di dalam sub bab berikut ini:

Kitab Syarḥ al-Nawawì 'alá Muslim.

Dalam kitab ini, al-Nawawī memberikan penjelasan panjang lebar terkait dengan Hadīts di atas. Dari kitab syarh tersebut dapat dijelaskan bahwa melakukan perubahan terhadap kemungkaran merupakan bagian dari iman. Amar ma'rūf nahy mungkar merupakan dua hal yang diwajibkan. Al-Nawawī kemudian menjelaskan terkait dengan asbāb al-wurūd yang melatarbelakangi sampainya Hadīts tersebut. Dikatakan bahwa sahabat yang pertama kali mendahulukan khutbah sebelum dilaksanakannya salat 'I $\bar{d}$ adalah Marwān. Ada perbedaan di kalangan ulama terkait dengan sahabat pertama yang melakukan hal itu. Al-Qāẹī 'Iyāḍ berpendapat bahwa sahabat pertama yang melakukannya adalah 'Utsmān ibn 'Affān, adapula yang mengatakan bahwa sahabat yang melakukan untuk pertama kalinya adalah 'Umar ibn al-Khaț̣āb, Zubayr, dan adapula yang mengatakan Mu'āwiyah. Hal itu dilakukan karena setiap kali pelaksanaan salat 'İd dengan mendahulukan salat kemudian khutbah, seringkali orangorang pulang tanpa mendengarkan khutbah terlebih dahulu setelah 
selesai salat. Ada sementara pendapat yang mengatakan bahwa pengakhiran khutbah tersebut bertujuan agar orang-orang yang datang terlambat dapat mendapati salat, demikian juga orang-orang yang jarak rumahnya berjauhan dengan tempat pelaksanaan salat.

Lebih lanjut al-Nawawī menjelaskan tentang kejadian yang melatarbelakangi kemunculan Hadīts tersebut, bahwa saat itu Abū Sa 'īd al-Khuḍrī hadir akan tetapi ia tidak langsung menanggapi apa yang dilakukan Marwān. Hal itu dimungkinkan adanya pertimbangan, jika dia melakukan taghyīr al-Munkar ia khawatir terjadinya "fitnah" baik bagi dirinya maupun orang lain, sehingga ia menahan diri untuk melakukannya. Sedangkan sahabat lain tidak demikian. ${ }^{12}$

Al-Nawawī kemudian menjelaskan juga bahwa dalam rangka amar makruf nahi mungkar tidak disyaratkan bagi orang yang melakukannya memunyai pribadi yang sempurna, dalam arti bahwa orang tersebut terlebih dahulu harus melakukan apa yang diperintahkannya maupun meninggalkan apa yang ditinggalkannya. Kalau pribadi orang tersebut belum sempurna, maka kewajiban orang tersebut menjadi ganda, artinya dia wajib mengingatkan dirinya dan orang lain. Para ulama juga berpendapat bahwa amr ma'rūf nahy mungkar tidak hanya dikhususkan hanya kepada orang-orang yang berkuasa saja, namun hal itu boleh dilakukan oleh setiap pribadi Muslim. Namun demikian, ada perbedaan terkait kewenangan masing-masing pribadi dalam pelaksanaan amar makruf nahi mungkar. Jika perkara tersebut termasuk ke dalam perkara yang diketahui oleh setiap pribadi Muslim tentang kewajiban dan keharamannya, maka setiap Muslim berhak melaksanakan amar makruf nahi mungkar, namun jika perkara tersebut hanya diketahui oleh sebagian orang saja, maka yang berhak adalah mereka yang memahami perkara tersebut. Kemudian perlu dijelaskan di sini, bahwa perkara yang menjadi obyek amar makruf nahi mungkar adalah perkara yang sudah disepakati para ulama, bukan perkara $i j t i h \bar{a} d \bar{\imath}$ atau yang masih diperselisihkan di antara para ulama. ${ }^{13}$

Penting disebutkan pula bahwa tindakan amr ma'rūf nahy mungkar juga harus memertimbangkan kemungkinan dari akibat yang ditimbulkan. Menurut para ulama, jika menurut sangkaan yang kuat bahwa mengubah sebuah kemungkaran dapat menyebabkan 
terjadinya kemungkaran yang lebih berat, seperti terbunuhnya orang yang melakukan atau orang lain, maka hal itu hendaknya dihindari dan mencukupkan diri dengan memberi peringatan atau nasehat untuk meninggalkan kemungkaran tersebut, bahkan jika itu pun menyebabkan celaan dari orang yang berbuat kemungkaran, maka dicukupkan taghyir al-Munkar dengan hati. Dan jika ditemukan orang lain yang mendukung terwujudnya amar makruf nahi mungkar, maka hal itu diperbolehkan dengan catatan tetap tidak menggunakan cara kekerasan (misalnya dengan menggunakan senjata), dan jika dimungkinkan terjadinya hal tersebut, maka langkah selanjutnya jika memungkinkan adalah mengangkat masalah tersebut kepada pihak-pihak yang berwenang. Hal ini sesuai dengan pendapat dari alHaramayn, dan jika tidak memungkinkan maka mencukupkan diri dengan taghyīr al-Munkar dengan hati. ${ }^{14}$

Selanjutnya, nahy mungkar dengan hati bukan berarti meniadakan iman seseorang yang melakukannya. Pernyataan ini diperkuat dengan Hadīts yang diriwayatkan oleh para perawi tsiqqah yang artinya:

"Diriwayatkan dari Șāliḥ ibn Kaysān dan al-Ḥarts dari Ja ‘far ibn 'Abdullāh ibn al-Ḥakam dari 'Abd al-Rahmān ibn al-Miswar dari Abū Rāfî̀ dari 'Abdullāh ibn Mas'ūd. Sesungguhnya Rasulullah bersabda: "Tidak seorang pun nabi yang diutus Allah kepada umat sebelumku, kecuali disertai orang-orang yang menolongnya dan menemaninya, mereka menjalankan sunnahnya serta mengikuti perintahnya. Kemudian datanglah segolongan orang yang mengucapkan sesuatu yang tidak mereka perbuat dan melakukan sesuatu yang tidak diperintahkan. Barang siapa yang menentang mereka dengan "tangan" nya maka dia mukmin, dan barang siapa menentang mereka dengan lisannya maka dia mukmin, dan barang siapa yang menentang mereka dengan hatinya maka dia mukmin. Dan jika tidak menentangnya maka tidak sebiji sawi pun tersisa iman darinya. ${ }^{15}$

\section{Tuhfat al-Ahwaži Syarh Șahīh al-Tirmīzī}

Di dalam kitab ini, al-Mubārakfūrī mengawalinya dengan penjelasan terhadap asbāb al-wurūd yang melatarbelakangi kemunculan Hadìts tersebut. Khususnya terkait dengan lafaz "khälafat al-sunnah". Lafaz ini kemudian dikomentari olehnya 
dengan mengatakan bahwa praktik pelaksanaan khutbah seperti yang dilakukan oleh Nabi, Abū Bakr, 'Umar dan 'Utsmān secara ijmā' adalah salat terlebih dahulu kemudian dilanjutkan dengan khutbah. Ia juga mengutip pendapat al-Nawawī yang mengatakan bahwa terjadinya ikhtiläf tersebut pada masa kekhalifahan bani Umayyah. Penjelasan lain terhadap teks Hadīts, tidak banyak berbeda dari yang ada di dalam kitab syarh lainnya, meskipun lebih ringkas. Misalnya ketika menjelaskan maksud dari mengubah kemungkaran dengan "tangan", dengan mengutip penjelasan yang dikemukakan oleh al-Bukhārī dan Muslim yaitu dengan cara mencegah perbuatan mungkar dengan perbuatan, seperti merusak alat-alat kemaksiatan, membuang khamr, atau mengembalikan barang yang dikuasai secara zalim kepada pemiliknya.

Setelah itu, jika orang tersebut tidak mampu melakukan dengan "tangan" disebabkan karena kuatnya orang yang melakukan kemungkaran baik posisi maupun lainnya, maka kemudian beralih ke tingkatan yang kedua yaitu mengubah kemungkaan dengan lisan, yang dimaksudkan adalah dengan mengingatkannya, bisa dengan cara membacakan ayat al-Qur'ān yang berisi ancaman terhadap perbuatan maksiat yang dilakukan, dengan menasehati, maupun dengan menakut-nakuti. Kemudian jika hal itu juga tidak mungkin untuk dilakukan, maka mengubahnya dengan kekuatan hati, yaitu dengan cara tidak rida dan mengingkari perbuatan maksiat di dalam batin. Dengan demikian, mengubah kemungkaran dengan cara yang terakhir ini merupakan taghyīr inkār maknawi. Meskipun demikian, hal itu termasuk ke dalam taghyir al-Munkar.

Hal yang membedakan dari kitab lain adalah adanya penjelasan yang cukup terkait dengan maksud dari matn Hadīts "aḍ'af al-imān". Terkait dengan penjelasan lafaz tersebut, ada beberapa pendapat, yaitu:

Pertama, yang dimaksud adalah cerminan dari lemahnya iman seseorang. Maksudnya adalah taghyir al-Munkar bil-qalb merupakan cerminan kelemahan iman seseorang. Oleh karena itu dapat dijelaskan bahwa barang siapa yang tidak melalui tingkatan-tingkatan dalam beramar makruf nahi mungkar, dari mulai dengan tangan dan seterusnya padahal dia mampu melakukannya, maka hal itu dianggap 
sebagai sebuah kemaksiatan, dan barang siapa yang meninggalkan tingkatan tersebut karena alasan tidak mampu, atau dikhawatirkan terjadinya kerusakan yang lebih besar, kemudian melakukannya dengan "hati" maka orang tersebut masuk ke dalam kelompok orangorang yang beriman

Kedua, yang dimaksud adalah dengan melakukan taghyìr alMunkar hanya dengan hati, maka hal itu menunjukkan atas lemahnya iman masa itu. Sebab jika keimanan orang-orang pada suatu masa itu kuat, maka niscaya mereka mampu mengubah kemungkaran baik dengan ucapan maupun perbuatan. Dan jika seseorang hanya mencukupkan dengan mengubah kemungkaran hanya dengan hati, maka hal itu menunjukkan lemahnya iman seseorang.

Dari penjelasan di atas, maka dapat disimpulkan bahwa tindakan untuk mengubah kemungkaran dengan "tangan" bukan merupakan tindakan satu-satunya. Bahkan jika mengubah kemungkaran itu dapat menyebabkan timbulnya risiko yang lebih besar, maka hal itu membolehkan seseorang berpindah ke cara yang lain, baik dengan cara menasehati (taghyīr al-Munkar bil-lisān), maupun dengan cara (inkār bil-qalb), meskipun cara terakhir ini mengindikasikan orang yang melakukannya imannya lemah. Tetapi tetap dinilai sebagai orang yang beriman. ${ }^{16}$

\section{Hāshiyat al-Sindī 'alā Sunan al-Nasā̄ì}

Sama seperti kitab lainnya, yang membedakan adalah penjelasan tentang makna matn Hadìts "ad'af al-imān". Dalam kitab syarah ini, pemaknaan "iman yang lemah" adalah lemahnya amal yang merupakan cerminan keimanan yang terkait dengan inkār alMunkar (mengingkari kemungkaran) hal itu dilihat dari dzätīyah perbuatannya, bukan melihat orang yang tidak mampu mengubah kemungkaran. ${ }^{17}$

\section{Hāshiyat al-Suyūtī 'alā al-Nasā̄î̀}

Dalam menjelaskan makna matn Hadīts tentang amr ma'rūf nahy mungkar di atas, al-Suyūṭi mengutip apa yang dikemukakan oleh 'Izz al-Dīn ibn 'Abd al-Salām, yang mengatakan bahwa ada dua pertanyaan terkait dengan Hadīts tersebut. Pertama, apakah yang 
dimaksud dengan orang yang melakukan taghyīr al-Munkar bil-lisān dan bil-qalb secara bersamaan? Kedua lafaz "ad'af al-ìmān" di atas mengandung kemusykilan, karena hal itu menunjukkan dicelanya orang yang melakukan taghyīr al-Munkar dengan hati. Selain itu, terkadang orang yang memunyai tingkat keimanan yang tinggi pun tidak mampu melakukan taghyir al-Munkar dengan tangan. Sehingga bukan berarti ketidakmampuan mengubah kemungkaran menjadi indikasi lemahnya iman seseorang. Sementara, di dalam Hadits hal itu disebut dengan iman yang lemah.

sJawaban dua pertanyaan tersebut adalah, pertama yang dimaksudkan dengan mengubah kemungkaran baik secara lisan maupun hati bukanlah melakukan amr ma'rūf dengan dua cara dan dilakukan secara bersamaan, akan tetapi menggunakan cara bil-lisān disertai dengan pengingkaran dengan hati. Kedua, yang dimaksdukan dengan iman di dalam Hadìts tersebut adalah iman secara majāz yang diartikan dengan perbuatan. Atau dapat diartikan pula dengan perbuatan yang lemah. Penyebutan lafaz "ad'af al-ìmān" di dalam Hadīts tersebut bukan untuk menghina/mencaci orang yang mengubah kemungkaran dengan hati, akan tetapi bertujuan agar supaya seorang mu'min dapat mengetahui bahwa mengubah kemungkaran dengan hati tersebut merupakan tingkatan yang paling rendah, sehingga berusaha untuk melakukan tingkatan yang lebih tinggi dalam mengubah kemungkaran. ${ }^{18}$

\section{Hāsyiyat al-Sindī 'alá Ibn Mājjah}

Di dalam kitab ini, tidak ada perbedaan mendasar terkait dengan penjelasan dari beberapa kitab sebelumnya. Hanya saja, yang menarik adalah penyebutan $a s b \bar{a} b$ al-wurüd yang agak berbeda dari yang telah disebutkan di awal bab ini. Asbāb al-wurūd yang dikemukakan oleh al-Sindī adalah bahwa suatu ketika orang-orang banyak mencela orang-orang yang tidak boleh dicela pada waktu diberlangsungkannya khutbah. Kemudian orang-orang bercerai berai ketika mendengarkan khutbah jika khutbah itu dilakukan setelah salat. Sebab kejadian itu, maka khutbah kemudian dilaksanakan sebelum salat, agar mereka mendengarkannya. ${ }^{19}$ Selebihnya, penjelasan terhadap matn Hadīts, sama dengan beberapa kitab syarh Hadīts sebelumnya. 
Demikianlah beberapa penjelasan terkait dengan makna matn Hadīts tentang amr ma'rūf nahy mungkar. Selanjutnya untuk memerluas pembahasan ini, perlu dilakukan kajian lebih lanjut terkait dengan masalah amar makruf nahi mungkar dalam prespektif para ulama, baik salaf maupun khalaf. Setelah dilakukan penelusuran, ternyata ditemukan banyak literatur yang membahas secara khusus maupun tidak tema tersebut. Hal ini dapat dilihat dalam penjelasan berikut.

\section{Amar Makruf Nahi Mungkar Perspektif Ulama}

Tidak mengherankan jika pembahasan tentang amar makruf nahi mungkar banyak dibicarakan oleh para ulama. Hal ini mengingat pentingnya tema tersebut di dalam pandangan agama. Seperti yang telah dijelaskan di dalam bab sebelumnya, bahwa amr ma'rūf merupakan ruh risālah kenabian yang juga menjadi kewajiban bagi segenap umat Islam. Oleh karena itu, maka banyak literatur-literatur baik turāts maupun kekinian yang secara khusus maupun tidak membicarakan tentang amar makruf nahi mungkar. Al-Māwardī di dalam kitab al-Aḥkàm al-Sulțānīyah membuat klasifîkasi tindakan kemungkaran menjadi tiga bagian, yaitu: kemungkaran yang terjadi berkaitan dengan hak Allah, kemungkaran yang berkaitan dengan hak Allah dan hak manusia, dan kemungkaran yang berkaitan dengan hak manusia ${ }^{20}$

Kemungkaran yang berkaitan dengan hak Allah dibagi lagi menjadi tiga bagian, yaitu kemungkaran yang terkait dengan masalah ibadah, kemungkaran yang terkait dengan masalah larangan (mahzūrāt), dan kemungkaran yang terkait dengan masalah muamalat. Kemungkaran yang terkait dengan masalah ibadah, misalnya orang dengan sengaja melakukan ibadah tertentu dengan tata cara pelaksanaan yang berbeda dari ketentuan agama. Maka boleh bagi muhtasib mengingkari perbuatan tersebut, jika terbukti bahwa tindakan tersebut tidak sesuai dengan ajaran agama, serta orang yang melakukannya tidak dapat menyandarkan apa yang dilakukannya kepada ulama yang berpendapat tentang hal itu.

Sedangkan kemungkaran yang terkait dengan larangan-larangan agama, maka diperbolehkan bagi muhtasib untuk segera melarang atau 
mengingkarinya tanpa diawali dengan $t a^{\prime} d \bar{\imath} b$ (memberikan pengertian bagi orang yang melakukannya). Adapun kemungkaran yang terkait dengan perkara muamalat, seperti perbuatan zina, melakukan praktik jual beli yang tidak dibenarkan, dan segala perbuatan yang dilarang oleh syara', meskipun hal itu disepakati oleh masing-masing dari orang yang melakukan akad. Maka jika perbuatan tersebut disepakati oleh pihak terkait, sementara oleh para ulama dilarang, maka wajib bagi muhtasib untuk melarang perbuatan tersebut. Namun jika perbuatan tersebut diperselisihkan oleh para ahli hukum terkait dengan dilarang atau tidaknya perbuatan itu, maka tidak boleh bagi muhtasib untuk mengingkarinya, terkecuali jika perbedaan itu lemah dalam pandangan hukum Islam. ${ }^{21}$

\section{Kemungkaran yang terkait dengan Hak Allah dan Manusia}

Jika kemungkaran yang dilakukan terkait dengan hak Allah dan manusia secara bersamaan, misalnya meninggikan bangunan secara berlebihan yang mengganggu keberadaan rumah di sebelahnya dan lain sebagainya, maka boleh bagi muhtasib untuk mengingkarinya tanpa diawali dengan $t a^{\prime} d \bar{l} b$ (memberi pelajaran). ${ }^{22}$

Jika kemungkaran yang terjadi terkait dengan hak-hak manusia, seperti penguasaan secara tidak sah terkait dengan hak orang lain, maka kewajiban bagi muhtasib adalah mendamaikan keduanya, dan jika berlanjut maka diserahkan kepada hakim untuk memutuskan perkara yang terjadi di antara keduanya. ${ }^{23}$

Dari beberapa contoh tindak kemungkaran di atas, maka dapat diambil sebuah kesimpulan bahwa tindakan yang perlu dilakukan guna menanggulangi kemungkaran, berbeda-beda sesuai dengan macam kemungkaran yang dilakukan.

\section{Tingkatan Pencegahan terhadap Tindak Kemungkaran}

Sebagaimana yang dijelaskan di awal pembahasan, bahwa di dalam usaha untuk taghyir al-Munkar ada beberapa cara, seperti yang telah dijelaskan di dalam Hadīts pada awal pembahasan ini, yaitu dengan cara menggunakan tangan atau kekuasaan, kemudian dengan lisan dan yang terakhir dengan hati. Masing-masing dari ketiga macam tersebut, dalam praktiknya terlebih dahulu harus memenuhi 
beberapa persyaratan dan penjelasan sebagai berikut:

\section{Mengubah kemungkaran dengan Tangan}

Taghyìr al-Munkar dengan cara ini merupakan tingkatan yang tertinggi dari beberapa cara yang ada dalam amar makruf nahi mungkar. Gambaran dari perwujudan cara ini adalah misalnya menumpahkan minuman keras dari orang yang meminumnya, merobohkan patung yang dijadikan sesembahan selain Allah, mewajibkan kepada orang lain untuk melaksanakan salat dan sebagainya.

Cara ini hanya diperbolehkan bagi orang yang memunyai kekuasaan terhadap orang yang melakukan tindakan kemungkaran, misalnya pemimpin, wakilnya atau orang yang menggantikannya, baik itu muhtasib atau lainnya yang ditunjuk oleh pemimpin. Atau setiap orang Muslim yang memunyai kekuasaan terhadap orang lain, misalnya orang tua kepada anaknya atau keluarganya. Namun demikian, cara ini tidak mutlak boleh dilakukan oleh setiap orang dan setiap kemungkaran, karena jika dimutlakkan, maka justru akan menyebabkan munculnya kemadaratan yang tidak diinginkan, ${ }^{24}$ dan hal ini tidak diperbolehkan.

Hal ini sejalan dengan apa yang diungkapkan oleh Ibn Taymīyah yang mengatakan: "Tidak setiap orang berhak menghilangkan kemungkaran yang terjadi di hadapannya, misalnya memotong tangan seorang pencuri, mendera orang yang minum khamr atau melaksanakan had. Karena jika semua orang berhak melakukannya tentunya akan mendatangkan kerusakan, karena setiap orang akan memukul orang lain dengan alasan dia berhak melakukannya. Oleh karena itu, pelaksanaan taghyìr al-Munkar dengan tangan khusus diperbolehkan bagi walì alamr"25

\section{Mengubah Kemungkaran dengan Lisan}

Cara ini dilakukan ketika cara yang pertama tidak mungkin untuk dilakukan. Dalam praktiknya, cara ini memunyai beberapa tahapan, yaitu pertama, memberitahu kepada orang yang melakukan kemungkaran dengan cara-cara yang halus. Hal itu dapat dilakukan dengan cara memberi isyarat bahwa apa yang dilakukan oleh seseorang adalah tindakan yang tidak dibenarkan oleh syari'at. Hal ini dilakukan 
dengan maksud agar orang yang diingatkan tersebut dapat menerima dan tidak menghindar dari ajaran agama. ${ }^{26} \mathrm{Hal}$ ini diperkuat dengan riwayat dari 'Â'isyah bahwa Rasulullah bersabda: "Inna Allāh yubibb al-rifq fì al-amr kullih” (Sesungguhnya Allah mencintai cara-cara yang halus dalam setiap perkara.) ${ }^{27}$

Hadīts di atas merupakan tanggapan Nabi terhadap 'Ā'isyah, ketika ada sekelompok orang-orang Yahudi datang kepada Nabi seraya mengatakan “Semoga engkau mati." Mendengar hal itu, 'Á'isyah secara spontan mereaksi tindakan Yahudi tersebut dengan ucapan "Semoga kalian mati dan dilaknat." Melihat hal itu, Rasulullah kemudian mengucapkan Hadīts di atas. ${ }^{28}$ Sikap yang ditunjukkan oleh Rasulullah tersebut semata-mata mengharap agar mereka mendapatkan petunjuk dan tidak memusuhi Islam. Selain itu, caracara halus dapat menghindarkan dari perbuatan menyakiti orang lain. Hal itu juga diperkuat dengan ayat al-Qur'ān: " $U d$ 'u ilá sabili rabbika bil-hikmah wa-al-mawizah al-hasanah wa-jädilhum billatī hiya ahsan” (Serulah (manusia) kepada jalan Tuhanmu dengan hikmah dan pelajaran yang baik dan bantahlah mereka dengan cara yang baik). ${ }^{29}$ Juga fīrman Allah: "Wa-la-tujādilū abl al-kitāb illā billatī hiya aḅsan illā al-ladzina zalamū minhum” (Dan janganlah kamu berdebat dengan Ahli Kitab, melainkan dengan cara yang paling baik, kecuali dengan orang-orang zalim di antara mereka). ${ }^{30}$

Ayat di atas ditujukan kepada Ahli al-Kitab yaitu orang-orang Yahudi, Nasrani dan orang-orang kafir, maka tentunya jika kita mengingatkan orang-orang mu'min harus lebih bisa bersikap halus dan lemah lembut. Bahkan al-Ghazālī mengatakan bahwa berbuat kasar dan menyakiti orang mu'min lainnya hukumnya adalah haram. ${ }^{31}$ Metode inilah yang telah dipraktikkan oleh generasi al-Salaf al-Șälih. ${ }^{32}$

Kedua, mencegah kemungkaran dengan cara menasehati dan menakut-nakuti terhadap ancaman Allah. Cara ini diterapkan kepada pelaku tindak kemungkaran yang mengetahui tentang hukum atau ajaran-ajaran agama. Terhadap kalangan ini, cara yang dipandang paling tepat adalah menasehati serta menakut-nakuti. ${ }^{33}$ Ketiga, mencegah kemungkaran dengan menggunakan kata-kata yang keras. Hal ini dilakukan ketika dua cara tersebut di atas tidak 
berhasil. Meskipun demikian tidak serta merta diperbolehkan menggunakan kata-kata keras tanpa batas, akan tetapi harus tetap menjaga ketentuan-ketentuan yang ditetapkan oleh syari'at agama, di antaranya tidak melakukannya kecuali dengan kejujuran serta tidak berlebih-lebihan. ${ }^{34}$ Cara ini sebagaimana yang dilakukan oleh Nabi Ibrāhīm, yang digambarkan di dalam fïrman Allah: "Uffin lakum walimà ta'budūna min dùn Allāh afalà táqilün." (Ah (celakalah) kamu dan apa yang kamu sembah selain Allah. Maka apakah kamu tidak memahami?)" 35

Keempat, mengancam pelaku kemungkaran. Tahapan ini adalah tahapan akhir dari mengubah kemungkaran dengan lisan. Gambaran cara ini dapat diwujudkan dengan kata-kata misalnya, "Jika kamu tidak menghentikan perbuatan mungkar, maka saya akan bertindak" atau dengan mengatakan "Jika kamu tidak menghentikan perbuatan mungkar, maka akan aku laporkan kepada penguasa”. ${ }^{36}$ Namun demikian, ancaman tersebut harus logis dan sesuai dengan aturan syari'at. $^{37}$

\section{Mengubah Kemungkaran dengan Hati}

Jika seseorang tidak lagi mampu melaksanakan taghyìr alMunkar dengan kedua cara tersebut di atas, maka baginya diwajibkan mengingkari perbuatan mungkar tersebut dengan hati. hal ini dapat diwujudkan dengan cara membeci perbuatan mungkar tersebut, dan tidak ada alasan baginya untuk tidak melakukannya. Mengubah kemungkaran dengan cara ini merupakan hal terendah yang dapat dilakukan. ${ }^{38}$ Penting dijelaskan di sini, bahwa mengubah perbuatan kemungkaran dengan tangan, bukanlah satu-satunya jalan untuk melakukan amar makruf nahi mungkar. Bahkan hal itu tidak boleh dilakukan, ketika dapat menimbulkan madarat yang lebih besar. ${ }^{39}$ Atas dasar inilah, al-Ghazālī menyatakan bahwa jika pelaku tindak kemungkaran adalah seorang pemimpin, maka metode yang boleh untuk mengubah kemungkaran itu adalah hanya dengan dua cara yaitu memberitahu dan nasihat. Hal ini untuk menghindari fitnah (kerusakan) yang timbul jika dilakukan dengan cara-cara yang ekstrim. ${ }^{40}$

Demikianlah beberapa tingkatan dalam usaha untuk mengubah 
kemungkaran. Meskipun para ulama berbeda pendapat terkait dengan tingkatan-tingkatan amar makruf nahi mungkar, namun pada prinsipnya, semua sepakat, bahwa mengubah tindakan kemungkaran harus memerhatikan syarat-syarat yang harus dipenuhi. Hal-hal tersebut di atas -berkaitan dengan syarat yang harus dipenuhi oleh seorang Muslim yang hendak melakukan amar makruf nahi mungkar, tingkatan-tingkatan dalam beramar makruf nahi mungkar, serta adab beramar makruf nahi mungkar- patut dijadikan sebagai acuan di dalam usaha untuk berdakwah ke jalan Allah.

\section{Simpulan}

Dari pembahasan di atas dapat diambil kesimpulan bahwa amar makruf nahi mungkar harus dilakukan sesuai dengan kemampuan orang yang hendak melakukannya. Di samping itu seseorang yang hendak beramr ma' rūf nahy mungkar harus memertimbangkan aspek mașlahah maupun mafsadah dari yang dilakukannya. Oleh karena itu, amar makruf nahi mungkar disyaratkan tidak menyebabkan mafsadat yang lebih besar daripada maslahatnya, atau seimbang. Bahkan jika nahy mungkar dapat menyebabkan kemungkaran lain yang lebih besar, maka nahy mungkar tidak lagi menjadi wajib dan tidak sah dilakukan (gugur kewajibannya).

\section{Catatan Akhir:}

1 Fazlur Rahman, Islam, terj. Ahsin Mohammad (Bandung: Pustaka, 1984), 68.

2 Abū Hāmid Muhammad ibn Muhammad ibn Muḥammad al-Ghazālī al-Ṭūsī, Ihyä' 'Ulüm al-Dīn (Beirut: Dār al-Fikr, 1987), Juz 2, 142.

3 Salmān ibn Fahd al-'Awdah dan Faḍlī Ilāhī, Amar Makruf Nahi Mungkar (Jakarta: Pustaka al-Kautsar, 1993), 11.

4 Salmān ibn Fahd al-'Awdah dan Faḍlī Ilāhī, Amar Makruf Nahi Mungkar, 1112.

5 Salmān ibn Fahd al-'Awdah dan Faḍlī Ilāhī, Amar Makruf Nahi Mungkar, 14.

${ }_{6}$ Bernas Jogja, Jum'at 6 Maret 2009.

7 www.wahidinstitute.com.

8 Jawa Pos, Selasa, tertanggal 3 Juni 2008, 15.

9 www.islamlib.com

${ }^{10}$ Abū Zakarīyā Yahyā ibn Syaraf al-Nawawī, Syarḥ al-Nawawì alà Sahịh Muslim (Beirut: Dār Ihyā' al-Turāts al-'Arabī, 1392 H), Juz 1, 22.

${ }^{11}$ Al-Nawawī, Syarh al-Nawawì 'alá Sahăh̆ Muslim, Juz 1, 22; Khālid ibn 'Utsmān al-Sabt, al-Amr bil-Ma'rüf wa-al-Nahy 'an al-Munkar Usüuluh wa-Dawäbituh 
wa-Ādābuh (Saudi Arabia: al-Muntadā al-Islāmī, 1995), 108-129.

${ }^{12}$ Al-Nawawī, Syarh al-Nawawì 'alá Sạhīh Muslim, Juz 2, 21-22.

${ }^{13}$ Al-Nawawī, Syarh al-Nawawi 'alá Șah̄ị Muslim, Juz 2, 23; lih. juga 'Umar 'Abd Allāh Kāmil, Kalimāt Hadīah fì al-Bid'ah (Yordan: Dār al-Muṣtafā, 2005), 10.

${ }^{14}$ Al-Nawawī, Syarh al-Nawawì 'alá Șah̄ị Muslim, Juz 2, 25.

${ }^{15}$ Muslim ibn al-Hajjāj Abū al-Husayn al-Qusyayrī al-Nīsābūrī, Șaḥ̄h Muslim (Beirut: Dār Ihyāà al-Turāts al-'Arabī, tt), Juz 1, 69; Kitāb al-İmān bāb Bayān Kawn al-Nahy 'an al-Munkar min al-İmān, wa-anna al-İmān Yazìd wa-Yanqus wa-anna al-Amr bil-Ma'rüf wa-al-Nahy 'an al-Munkar Wäjiban. No Hadīts. 71.

${ }^{16}$ Muhammad 'Abd al-Raḥmān ibn 'Abd al-Rahīm al-Mubārakfūrī Abū al-'Alā', Tuhffat al-Aḥwaz̄i bi-Syarh Jāmi‘ al-Tirmizzì (Beirut: Dār al-Kutub al-'Ilmīyah, tt), Juz 5, 464.

${ }^{17}$ Nūr al-Dīn ibn 'Abd al-Hādī Abū al-Hasan al-Sindī, Hāshiyat al-Sindī 'alá alNasā̄ì (Halb: Maktab al-Maṭbū'ah al-Islāmīyah, 1986), ditahqiq oleh 'Abd alFattāh Abū Ghuddah, Cet. II, Juz 6, 147.

18 'Abd al-Raḥmān ibn Abī Bakr Abū al-Fạ̣l al-Suyūṭī, Syarh al-Suyūtī li Sunan al-Nasā̄ì (Halb: Maktab al-Maṭbū'ah al-Islamīyah, 1986), ditahqiq oleh 'Abd al-Fattāh Abū Ghuddah, Cet. II, Juz 8, 112-113.

${ }^{19}$ Nūr al-Dīn ibn 'Abd al-Hādī Abū al-Hasan al-Sindī, Hāsyiyah al-Sindī 'alá Ibn Mãjjah (Halb: Maktab al-Maṭbū'ah al-Islāmīyah, 1986), ditahqiq oleh 'Abd alFattāh Abū Ghuddah, Cet. II, Juz 7, 380.

${ }^{20}$ Al-Māwardī, al-Ahkām al-Sultānīyah (Beirut: Dār al-Fikr, tt), Juz 1, 500.

${ }^{21}$ Al-Māwardī, al-Aḥkām al-Sulțānīyah (Beirut: Dār al-Fikr, tt), Juz 2, 1-11.

${ }^{22}$ Al-Māwardī, al-Ahkām al-Sulțānīyah (Beirut: Dār al-Fikr, tt), Juz 2, 81.

${ }^{23}$ Al-Māwardī, al-Ạ̣kām al-Sulțānīyah (Beirut: Dār al-Fikr, tt), Juz 2, 14.

${ }^{24}$ Hamūd ibn Ahmad al-Rāhilī, Qawāìd Muhimmah fì al-Amr bil-Ma'rūf wa-alNahy 'an al-Munkar 'alá Daw' al-Kitāb wa-al-Sunnah (Beirut: Mawqi' al-Islām, tt.), I/29.

${ }^{25}$ Ibn Taymīyah, Mukhtașar al-Fatāwā al-Miṣrīyah (Beirut: tp, tt), 580.

${ }^{26}$ Hamūd ibn Ahmad al-Rāhilī, Qawāìd Muhimmah, Juz 1, 32-33.

${ }^{27}$ Muḥammad ibn Ismā'īl ibn Ibrāhīm Abū 'Abd Allāh al-Bukhārī al-Ju'fī, Șaḥ̄̄ al-Bukhārī (Beirut: Dār Ibn al-Katsīr al-Yamāmah, 1987), Juz 5, 2242, Bāb alRifq fì al-Amr Kullih nomor Hadīts 5678; lih. juga Muslim ibn al-Hajjāj Abū al-Husayn al-Qusyayrī al-Nīsābūrī, Șah̄̄h Muslim (Beirut: Dār Ihyā̄ al-Turāts al-'Arabī, tt), Juz 4, 1706, Bāb al-Nahy 'an Ibtidä' Abl al-Kitāb wa-kayfa Yarudd al-Salàm minhum, nomor Hadìts 2165.

${ }^{28}$ Ibrāhīm ibn Muhammad al-Husaynī al-Dimasyqī, al-Bayān wa-al-Tárìff, Juz 1, 420-421.

${ }^{29}$ QS. al-Nahl: 125.

${ }^{30}$ QS. al-'Ankabūt: 46.

31 Al-Ghazālī, Ihyyā' 'Ulūm al-Dìn, Juz 2, 320.

${ }^{32}$ Hamūd ibn Aḥmad al-Rāhilī, Qawā'id Muhimmah, Juz 1, 34.

${ }^{33}$ Hamūd ibn Aḥmad al-Rāhilī, Qawāìd Muhimmah, Juz 1, 34.

${ }^{34}$ Hamūd ibn Aḥmad al-Rāhilī, Qawāìd Muhimmah, Juz 1, 37. 
324 Refleksi, Volume 13, Nomor 3, Oktober 2012

QS. al-Anbiyā': 36.

${ }^{36}$ Hamūd ibn Ahmad al-Rāhilī, Qawāìd Muhimmah, Juz 1, 38.

${ }^{37}$ Al-Ghazāìi, Ihyyà' 'Ulùm al-Dìn, II/420-422.

${ }^{38}$ Hamūd ibn Ahmad al-Rāhilī, Qawāid Muhimmah, Juz 1, 39.

${ }^{39}$ Khālid ibn 'Uthmān al-Sabt, al-Amr bil-Ma'rüf, 369.

${ }^{40}$ Al-Ghazālī, I Ihyà' 'Ulūm al-Dìn, Juz 2, 337. 